\title{
Aggressive tumors and difficult choices in acromegaly
}

\author{
Carmen A. Carrasco • Mônica Gadelha • \\ Marcos Manavela $\cdot$ Oscar D. Bruno
}

Published online: 1 December 2013

(c) The Author(s) 2013. This article is published with open access at Springerlink.com

\begin{abstract}
Purpose The current article looks at some of the factors associated with pituitary adenomas displaying unusually aggressive biological and clinical behaviour in patients with acromegaly.

Methods This was a retrospective, narrative review of previously published evidence chosen at the authors' discretion and presented from the perspective of a Latin American case study.

Findings and Conclusions Although most pituitary tumors in acromegalic patients are benign and nonaggressive many can behave more aggressively, compromising local surrounding structures. These lesions tend to respond poorly to somatostatin analogs, have a higher risk of recurrence after surgery and, thus, a worse prognosis. Patients with more aggressive tumors constitute a particular challenge, as they often require several therapeutic approaches and may be difficult to manage, especially when options are restricted due to limited resources.
\end{abstract}

Keywords Acromegaly · GH · IGF-1 - Aggressive tumors $\cdot$ Somatostatin analogs $\cdot$ Dopamine agonists

\footnotetext{
C. A. Carrasco

Departamento de Endocrinología, Facultad de Medicina, Pontificia Universidad Católica de Chile, Santiago, Chile

M. Gadelha

Endocrinology Section, Hospital Universitário Clementino Fraga Filho, Federal University of Rio de Janeiro, Rio de Janeiro, Brazil

M. Manavela $\cdot$ O. D. Bruno $(\bowtie)$

Division of Endocrinology, Hospital de Clínicas, University of Buenos Aires, Av. Córdoba 2351, 1120 Buenos Aires, Argentina e-mail: bodomingo@intramed.net
}

\section{Introduction}

Most pituitary tumors in acromegalic patients are benign and respond well to multimodal therapy [1]. Nevertheless, many pituitary adenomas can behave in a more aggressive manner, with more rapid growth, local invasion into the surrounding structures, greater risk of recurrence after surgery and worse prognosis [1-3]. Patients with invasive and more aggressive $\mathrm{GH}$-secreting tumors often require several therapeutic approaches and may be difficult to manage [1], especially when options are restricted due to limited resources. The current article presents a case report of a somatotropic tumor with aggressive behavior and discusses some of the treatment challenges and difficult choices that this can impose in Latin America.

\section{What defines an aggressive tumor in acromegaly?}

Tumor aggressiveness can be based on clinical, radiological and pathological features. However, there are no welldefined absolute criteria for defining an aggressive pituitary tumor. The 2004 World Health Organization classification of pituitary tumors defined three primary types- "typical pituitary adenoma", "atypical pituitary adenoma" and "pituitary carcinoma" [4, 5]. The rather poorly defined "atypical" designation was an attempt to identify those adenomas that are likely to display more aggressive behavior with increased proliferative activity. The specific "atypical" characteristics that were identified included invasion into the cavernous sinuses, an elevated proliferation index [Ki-67 labeling index (LI) $>3 \%$ ] and nuclear reactivity for p. 53 [4]. However, the true value of these and other biomarkers in predicting aggressive and progressive tumor behavior in clinical practice remains 
uncertain [6, 7]. Many studies have found strong associations between Ki-67 labeling and tumor invasiveness, tumor size and recurrence, but there is inconsistency in the data, which may, at least in part, relate to the different criteria and measures used to define factors such as invasiveness [8]. Histologic subtyping may be the best predictor of aggressive behavior once surgical biopsies have been taken, particularly with regards to the presence of sparse granulation in somatotroph (i.e., growth hormonesecreting) adenomas, although subtyping into sparse versus dense granulation does not absolutely predict aggressiveness and many biopsies may show intermediate characteristics [7, 9, 11].

Radiological assessment of gross tumor invasiveness may be more clinically useful, especially as it can also provide an initial assessment of aggressive behavior obviating the need for intraoperative biopsies. At the time of acromegaly diagnosis, macroadenomas (tumors $>10 \mathrm{~mm}$ in diameter) represent approximately $80 \%$ of GH secreting adenomas [12-14]. Although definitions of invasiveness vary, approximately 25-50 \% of these macroadenomas can be defined as grossly invasive according to the most widely used radiological or surgical criteria (which are based on the degree of suprasellar extension or lateral extension into the cavernous sinus) [11$13,15-21]$. Around $50 \%$ or more of tumors might be considered as invasive if microscopic invasion of the local dura is employed as the criterion [22, 23].

Several other clinically-relevant factors such as young age at diagnosis, large tumor size, and high GH secretion have also been identified as predictors of aggressive behavior [1]. Although pediatric cases of acromegaly are uncommon, these cases may present with more aggressive and larger tumors and, as such, may require more intensive management [24, 25].

\section{Resistance to therapy}

As expected, the surgical cure rate is reduced for invasive tumors and many may be considered inoperable, thus necessitating other options, such as pharmacological intervention. In general, the surgical long-term remission rate for microadenomas is approximately $80 \%$, but this decreases to less than $50 \%$ for macroadenomas and only 25-30 \% for macroadenomas classified as grossly invasive $[12,13]$. Extrasellar tumor growth, mixed tumors (GH- and prolactin-secreting), dural invasion, tumor size, cavernous sinus invasion, Knosp grade, and pre-operative $\mathrm{GH}$ and IGF-1 levels have all been shown to be predictors of poor surgical outcome [26, 27]. Persistent disease after surgery might require repeat surgery, which is indicated if there is residual tumor that is surgically accessible with a chance for surgical cure (or with persistent mass effects on the optic chiasm) [28], although pharmacological therapy is indicated if this is not the case.

Resistance to pharmacological therapy may be another manifestation of aggressive disease. In the case of somatostatin analogs (SSAs) many factors have been identified that predict a better response and some of these may be worth considering before commencing therapy [29]. For instance, older age and lower circulating GH levels at diagnosis have all been associated with better SSA response, and a positive acute SSA test (showing $75 \% \mathrm{GH}$ reduction) may also help to predict longer-term responsiveness [29, 30]. Other accessible measures, such as a hyperintense lesion on T2-weighted on MRI can predict a poor response, as can the presence of sparse GH tumor granulation histology $[11,29]$. Various immunohistochemical assays for biochemical markers, such as Ki-67 LI (which is lower in responders), somatostatin receptor subtype 2 (SSTR2) expression, SSTR2/SSTR5 ratio and especially wild-type aryl hydrocarbon receptor-interacting protein (AIP) expression (which are all increased in responders) may also be useful for predicting response if biopsies are available. Recent data suggest that AIP can predict response to SSA therapy independently of SSTR2 expression, whereas the combination of both high AIP and high SSRT2 expression appears to be a particularly good predictor [31, 32]. Recent evidence also suggests that SSAs increase the expression of AIP and that it might play an important role in their mechanism of action [33]. However, these markers are not well validated in clinical practice and may not be widely available due to cost restrictions [29]. Nevertheless, if available, such factors may help to inform clinicians when making decisions about costly therapies.

The use of surgery to reduce tumor mass may help to improve the response to SSAs treatment in those resistant to primary SSAs therapy [34]. However, in those patients in whom all surgical and pharmacological approaches have failed to control the disease, radiotherapy is the only viable option [35, 36]. That said, novel pharmacological interventions are being investigated for the treatment of particularly aggressive pituitary tumors, most notably the orally administered alkylating agent temozolomide [37, 38]. However, experience with these agents specifically in patients with aggressive GH-secreting adenomas is extremely limited at present.

\section{Case study: difficult choices in a patient with invasive macroadenoma}

- A 31-year-old man was referred by his cardiologist because of acral growth and deformity of facial features

- He was noted to have hypertension and impaired glucose tolerance 3-years earlier 

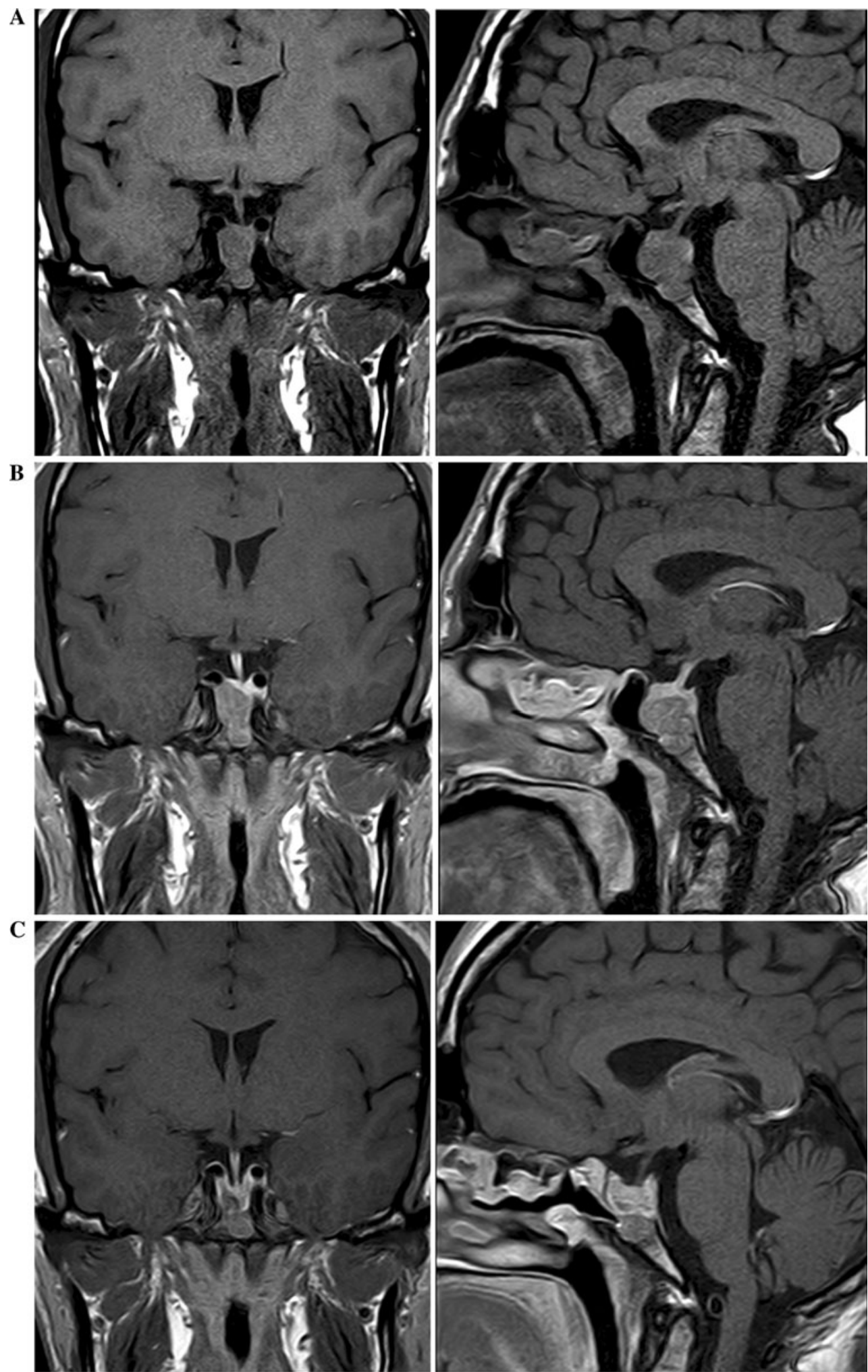

Fig. 1 Case study: post-contrast, T1-weighted MRI scans of pituitary tumor at diagnosis (a), before surgery (b) and three months after surgery (c) (coronal left, sagittal right) 
- He also complained of fatigue and headache, arthralgia, carpal tunnel syndrome and erectile dysfunction

- Past medical history and familial history were unremarkable

Physical examination (initial evaluation)

- Clinical findings were hypertension, acral enlargement, prognathism, supracilliary arch prominence, macroglossia, gynecomastia and thickened skin

- No visual field defects

Hormonal evaluation

- $\mathrm{GH}$ nadir during $\mathrm{OGTT}=17.3 \mu \mathrm{g} / \mathrm{L} \quad[2-\mathrm{h} \quad$ glucose $=8.8 \mathrm{mmol} / \mathrm{L}(158 \mathrm{mg} / \mathrm{dL})]$

- IGF-1: 1,162 $\mu \mathrm{g} / \mathrm{L}$ (normal 117-329 $\mu \mathrm{g} / \mathrm{L}$ )

- T4: $103 \mathrm{nmol} / \mathrm{L}[8.0 \mu \mathrm{g} / \mathrm{dL}$ (normal 4.6-12 $\mu \mathrm{g} / \mathrm{dL}$ )]

- TSH: $2.1 \mathrm{mIU} / \mathrm{L}$ (normal 0.3-4.1 mIU/L)

- Total testosterone: $5.5 \mathrm{nmol} / \mathrm{L}$ [159 ng/dL (normal 280-1,100 ng/dL)]

- Prolactin: $11.6 \mathrm{nmol} / \mathrm{L}$ [267 $\mu \mathrm{g} / \mathrm{L}$ (normal 2-20 $\mu \mathrm{g} / \mathrm{L}$ )]

- Basal cortisol/post Synacthen: 196/737 nmol/L (7/ $27 \mu \mathrm{g} / \mathrm{dL}$ )

Pre-treatment MRI

- Post-contrast coronal T1 MRI showed $18 \times 13 \mathrm{~mm}$ macroadenoma in the right and inferior portion of the pituitary, with invasion of sphenoidal sinus and erosion of sphenoid and clivus. Tumor had hypointense signal and normal hypophysis showed homogeneous enhancement at left (Fig. 1a, b)

Diagnosis

- Acromegaly (with co-secretion of prolactin)

- Invasive macroadenoma without mass effect

- Hypogonadotrophic hypogonadism

Initial treatment

- Transsphenoidal surgery was performed (June 2009) in an attempt to improve the response to cabergoline or radiation therapy (SSAs were not included in medical insurance in Chile at the time of diagnosis)

- Histopathology evaluation showed positive staining for $\mathrm{GH}$ and prolactin, perinuclear cytokeratin staining (densely granulated) and Ki-67 LI $4.7 \%$

- Predictors of poor surgical outcome were extrasellar growth (clivus invasion) and mixed tumor

3-Months follow-up

- IGF-1 $1193 \mu \mathrm{g} / \mathrm{L}$ (normal 115-307 $\mu \mathrm{g} / \mathrm{L}$ )

- Random GH $10.2 \mu \mathrm{g} / \mathrm{L}$

- GH nadir $8.6 \mu \mathrm{g} / \mathrm{L}$

- MRI: $13 \mathrm{~mm}$ clivus residual tumor (Fig. 1c)
Subsequent treatment and course

- Cabergoline (3-5 mg weekly) was initiated in September 2009 without obtaining normalization of IGF-1

- Radiation therapy was performed in June 2010 without normalization of IGF-1

- In July 2010, SSAs were initiated as add-on therapy to cabergoline

- Biochemical cure was not achieved despite maximal doses of SSA

- Currently, random $\mathrm{GH}$ is $1.58 \mu \mathrm{g} / \mathrm{L}$ (ECLIA), IGF-1 $650 \mu \mathrm{g} / \mathrm{L}$, hypertension and impaired glucose tolerance are under control and no symptoms of obstructive sleep apnea are present. The patient complains of fatigue and joint pain

\section{Case discussion}

This case provides an example of the difficult choices that have to be made in situations where access to some therapies is limited by local constraints, such as lack of reimbursement for specific drugs. The recommended first-line therapy in this patient was an SSA (possibly in combination with a dopamine agonist due to prolactin co-secretion). Due to the invasiveness of the tumor, the patient had a low chance of surgical cure. However, due to lack of access to SSAs at the time of diagnosis, a treatment plan had to be made based on the available local resources-in this case, surgery followed by cabergoline. Although the patient did not achieve biochemical remission even after SSAs became available, the patient has remained relatively stable. This introduces another dilemma regarding decisions to continue a pharmacological therapy or withdraw it and put the patient at risk of deterioration. Pressure to withdraw costly long-term pharmacological therapy may be considerable in areas with limited resources. Region-specific cost analyses would be useful to justify long-term pharmacological therapy in such situations. A further dilemma is whether to accept stable, but suboptimal, disease control or to intensify therapy further with additional cost. Guidelines recommend that patients should remain on the same dose for at least 3 months (assuming the patient tolerates the medication) to properly assess adequacy of treatment and the need for dose titration or switching to the $\mathrm{GH}$ receptor antagonist pegvisomant [39]. In the current case, intensification of pharmacological therapy beyond SSAs using the $\mathrm{GH}$ receptor antagonist pegvisomant was not possible, as it was not included in Chilean medical insurance programs.

\section{Conclusions}

Choosing the correct individually tailored therapeutic option in a patient with acromegaly in line with current 
guidelines is a challenge, even when access to all available surgical, pharmacological and radiotherapeutical resources is available. This is particularly true in patients with more aggressive disease. Failure to achieve hormonal control in acromegaly puts patients at risk for early mortality, suggesting the need for aggressive efforts to normalize hormone levels [40]. In patients with aggressive, invasive tumors, access to all available options thus becomes paramount. The prognosis of surgery will depend on the characteristics of the tumor, but importantly, also on the experience of the neurosurgeon when it comes to treat patients with more invasive tumors [26].

The SSAs have a role as primary pharmacological therapy and as adjuvant therapy after surgery or radiation in patients with aggressive tumors. Newer drugs such as GH receptor antagonists can be effective in normalization of IGF-I in patients who do not respond to SSAs, but with a very high cost and access to these drugs may not be possible in many areas of Latin America [41, 42]. Combination therapy with SSAs and a GH receptor antagonist may be a safe and effective option that can help to lower doses and reduce the costs of pharmacological treatment [43-45]. Lower cost, but less effective, medications, such as dopamine agonists maybe the only pharmacological options available in areas with restricted resources. Fortunately, SSAs are becoming more widely available across Latin American countries and the use of pharmacological therapy has increased markedly over the last 10 years. Further development of the use of biomarkers to predict aggressive and invasive tumor behavior, as well as response to pharmacological therapy may help clinicians to make more informed treatment choices early and make more effective use of available resources.

In summary, in countries with less access to experienced pituitary surgeons and with limited access to all available pharmacological therapies, management of aggressive $\mathrm{GH}$ tumors is particularly complex and physicians may need to make difficult choices based on available resources. Methods to improve judicious treatment selection, such as the use of histological evaluation or development of new reliable and accessible biomarkers predicting response to therapy, may provide a means to optimize resource utilization.

Acknowledgments The Latin American Knowledge Network Initiative, including meetings and preparation of this supplement, was organized and funded by Ipsen. Medical writing support was provided by Patrick Covernton on behalf of Arsenal-CDM Paris and funded by Ipsen. The authors were fully responsible for the concept and all content, were involved at all stages of manuscript development, and provided approval of the final version for submission.

Open Access This article is distributed under the terms of the Creative Commons Attribution License which permits any use, distribution, and reproduction in any medium, provided the original author(s) and the source are credited.

\section{References}

1. Besser GM, Burman P, Daly AF (2005) Predictors and rates of treatment-resistant tumor growth in acromegaly. Eur J Endocrinol 153(2):187-193

2. Buchfelder M (2009) Management of aggressive pituitary adenomas: current treatment strategies. Pituitary 12(3):256-260

3. Colao A, Grasso LF, Pivonello R, Lombardi G (2011) Therapy of aggressive pituitary tumors. Expert Opin Pharmacother 12(10): $1561-1570$

4. Al-Shraim M, Asa SL (2006) The 2004 World Health Organization classification of pituitary tumors: what is new? Acta Neuropathol 111(1):1-7

5. Kontogeorgos G (2006) Predictive markers of pituitary adenoma behavior. Neuroendocrinology 83(3-4):179-188

6. Gejman R, Swearingen B, Hedley-Whyte ET (2008) Role of Ki67 proliferation index and 553 expression in predicting progression of pituitary adenomas. Hum Pathol 39(5):758-766

7. Mete O, Ezzat S, Asa SL (2012) Biomarkers of aggressive pituitary adenomas. J Mol Endocrinol 49(2):R69-R78

8. Salehi F, Agur A, Scheithauer BW, Kovacs K, Lloyd RV, Cusimano M (2009) Ki-67 in pituitary neoplasms: a review-part I. Neurosurgery 65(3):429-437

9. Obari A, Sano T, Ohyama K, Kudo E, Qian ZR, Yoneda A, Rayhan N, Mustafizur Rahman M, Yamada S (2008) Clinicopathological features of growth hormone-producing pituitary adenomas: difference among various types defined by cytokeratin distribution pattern including a transitional form. Endocr Pathol 19(2):82-91

10. Kiseljak-Vassiliades K, Shafi S, Kerr JM, Phang TL, Kleinschmidt-DeMasters BK, Wierman ME (2012) Clinical implications of growth hormone-secreting tumor subtypes. Endocrine 42(1): $18-28$

11. Larkin S, Reddy R, Karavitaki N, Cudlip S, Wass J, Ansorge O (2013) Granulation pattern, but not GSP or GHR mutation, is associated with clinical characteristics in somatostatin-naive patients with somatotroph adenomas. Eur J Endocrinol 168(4): 491-499

12. Beauregard C, Truong U, Hardy J, Serri O (2003) Long-term outcome and mortality after transsphenoidal adenomectomy for acromegaly. Clin Endocrinol (Oxf) 58(1):86-91

13. Minniti G, Jaffrain-Rea M-L, Esposito V, Santoro A, Tamburrano G, Cantore G (2003) Evolving criteria for post-operative biochemical remission of acromegaly: can we achieve a definitive cure? An audit of surgical results on a large series and a review of the literature. Endocr Relat Cancer 10(4):611-619

14. Mestron A, Webb SM, Astorga R, Benito P, Catala M, Gaztambide S, Gomez JM, Halperin I, Lucas-Morante T, Moreno B, Obiols G, de Pablos P, Paramo C, Pico A, Torres E, Varela C, Vazquez JA, Zamora J, Albareda M, Gilabert M (2004) Epidemiology, clinical characteristics, outcome, morbidity and mortality in acromegaly based on the Spanish Acromegaly Registry (Registro Espanol de Acromegalia, REA). Eur J Endocrinol 151(4):439-446

15. Scheithauer BW, Kovacs KT, Laws ER Jr, Randall RV (1986) Pathology of invasive pituitary tumors with special reference to functional classification. J Neurosurg 65(6):733-744

16. Knosp E, Steiner E, Kitz K, Matula C (1993) Pituitary adenomas with invasion of the cavernous sinus space: a magnetic resonance imaging classification compared with surgical findings. Neurosurgery 33(4):610-617

17. Thapar K, Kovacs K, Stefaneanu L, Scheithauer B, Killinger DW, Lioyd RV, Smyth HS, Barr A, Thorner MO, Gaylinn B, Laws ER Jr (1997) Overexpression of the growth-hormone-releasing hormone gene in acromegaly-associated pituitary tumors. An event 
associated with neoplastic progression and aggressive behavior. Am J Pathol 151(3):769-784

18. Esposito V, Santoro A, Minniti G, Salvati M, Innocenzi G, Lanzetta G, Cantore G (2004) Transsphenoidal adenomectomy for GH-, PRL- and ACTH-secreting pituitary tumors: outcome analysis in a series of 125 patients. Neurol Sci 25(5):251-256

19. Saeger W, Lüdecke DK, Buchfelder M, Fahlbusch R, Quabbe HJ, Petersenn S (2007) Pathohistological classification of pituitary tumors: 10 years of experience with the German Pituitary Tumor Registry. Eur J Endocrinol 156(2):203-216

20. Kim MS, Jang HD, Kim OL (2009) Surgical results of growth hormone-secreting pituitary adenoma. J Korean Neurosurg Soc 45(5):271-274

21. Dusek T, Kastelan D, Melada A, Baretic M, Skoric Polovina T, Perkovic Z, Giljevic Z, Jelcic J, Paladino J, Aganovic I, Korsic M (2011) Clinical features and therapeutic outcomes of patients with acromegaly: single-center experience. J Endocrinol Invest 34(11):e382-e385

22. Selman WR, Laws ER Jr, Scheithauer BW, Carpenter SM (1986) The occurrence of dural invasion in pituitary adenomas. J Neurosurg 64(3):402-407

23. Meij BP, Lopes MB, Ellegala DB, Alden TD, Laws ER Jr (2002) The long-term significance of microscopic dural invasion in 354 patients with pituitary adenomas treated with transsphenoidal surgery. J Neurosurg 96(2):195-208

24. Dyer EH, Civit T, Visot A, Delalande O, Derome P (1994) Transsphenoidal surgery for pituitary adenomas in children [with discussion]. Neurosurgery 34(2):207-212

25. Abe T, Tara LA, Lüdecke DK (1999) Growth hormone-secreting pituitary adenomas in childhood and adolescence: features and results of transnasal surgery. Neurosurgery 45(1):1-10

26. Kreutzer J, Vance ML, Lopes MB, Laws ER Jr (2001) Surgical management of GH-secreting pituitary adenomas: an outcome study using modern remission criteria. J Clin Endocrinol Metab 86(9):4072-4077

27. Jane JA Jr, Starke RM, Elzoghby MA, Reames DL, Payne SC, Thorner MO, Marshall JC, Laws ER Jr, Vance ML (2011) Endoscopic transsphenoidal surgery for acromegaly: remission using modern criteria, complications, and predictors of outcome. J Clin Endocrinol Metab 96(9):2732-2740

28. Espinosa de los Monteros AL, González B, Vargas G, Sosa E, Guinto G, Mercado M (2009) Surgical reintervention in acromegaly: is it still worth trying? Endocr Pract 15(5):431-437

29. Gadelha MR, Kasuki L, Korbonits M (2013) Novel pathway for somatostatin analogs in patients with acromegaly. Trends Endocrinol Metab 25(5):238-248

30. Colao A, Auriemma RS, Lombardi G, Pivonello R (2011) Resistance to somatostatin analogs in acromegaly. Endocr Rev 32(2):247-271

31. Kasuki L, Colli LM, Elias PC, de Castro M, Gadelha MR (2012) Resistance to octreotide LAR in acromegalic patients with high SSTR2 expression: analysis of AIP expression. Arq Bras Endocrinol Metabol 56(8):501-506

32. Kasuki L, Vieira Neto L, Wildemberg LE, Colli LM, de Castro M, Takiya CM, Gadelha MR (2012) AIP expression in sporadic somatotropinomas is a predictor of the response to octreotide LAR therapy independent of SSTR2 expression. Endocr Relat Cancer 19(3):L25-L29
33. Chahal HS, Trivellin G, Leontiou CA, Alband N, Fowkes RC, Tahir A, Igreja SC, Chapple JP, Jordan S, Lupp A, Schulz S, Ansorge O, Karavitaki N, Carlsen E, Wass JA, Grossman AB, Korbonits M (2012) Somatostatin analogs modulate AIP in somatotroph adenomas: the role of the ZAC1 pathway. J Clin Endocrinol Metab 97(8):E1411-E1420

34. Jallad RS, Musolino NR, Kodaira S, Cescato VA, Bronstein MD (2007) Does partial surgical tumour removal influence the response to octreotide-LAR in acromegalic patients previously resistant to the somatostatin analogue? Clin Endocrinol (Oxf) 67(2):310-315

35. Jallad RS, Musolino NR, Salgado LR, Bronstein MD (2007) Treatment of acromegaly: is there still a place for radiotherapy? Pituitary 10(1):53-59

36. González B, Vargas G, Espinosa-de-los-Monteros AL, Sosa E, Mercado M (2011) Efficacy and safety of radiotherapy in acromegaly. Arch Med Res 42(1):48-52

37. Syro LV, Ortiz LD, Scheithauer BW, Lloyd R, Lau Q, Gonzalez R, Uribe H, Cusimano M, Kovacs K, Horvath E (2011) Treatment of pituitary neoplasms with temozolomide: a review. Cancer 117(3):454-462

38. Ortiz LD, Syro LV, Scheithauer BW, Rotondo F, Uribe H, Fadul CE, Horvath E, Kovacs K (2012) Temozolomide in aggressive pituitary adenomas and carcinomas. Clinics (Sao Paulo) 67(Suppl 1):119-123

39. Melmed S, Colao A, Barkan A, Molitch M, Grossman AB, Kleinberg D, Clemmons D, Chanson P, Laws E, Schlechte J, Vance ML, Ho K, Giustina A, Acromegaly Consensus Group (2009) Guidelines for acromegaly management: an update. J Clin Endocrinol Metab 94(5):1509-1517

40. Sughrue ME, Chang EF, Gabriel RA, Aghi MK, Blevins LS (2011) Excess mortality for patients with residual disease following resection of pituitary adenomas. Pituitary 14(3):276-283

41. Colao A, Pivonello R, Auriemma RS, De Martino MC, Bidlingmaier M, Briganti F, Tortora F, Burman P, Kourides IA, Strasburger CJ, Lombardi G (2006) Efficacy of 12-month treatment with the GH receptor antagonist pegvisomant in patients with acromegaly resistant to long-term, high-dose somatostatin analog treatment: effect on IGF-I levels, tumor mass, hypertension and glucose tolerance. Eur J Endocrinol 154(3):467-477

42. Barkan A, Bronstein MD, Bruno OD, Cob A, Espinosa-de-losMonteros AL, Gadelha MR, Garavito G, Guitelman M, Mangupli R, Mercado M, Portocarrero L, Sheppard M (2010) Management of acromegaly in Latin America: expert panel recommendations. Pituitary 13(2):168-175

43. Jørgensen JO, Feldt-Rasmussen U, Frystyk J, Chen JW, Kristensen LØ, Hagen C, Ørskov H (2005) Cotreatment of acromegaly with a somatostatin analog and a growth hormone receptor antagonist. J Clin Endocrinol Metab 90(10):5627-5631

44. Feenstra J, de Herder WW, ten Have SM, van den Beld AW, Feelders RA, Janssen JA, van der Lely AJ (2005) Combined therapy with somatostatin analogues and weekly pegvisomant in active acromegaly. Lancet 365(9471):1644-1646

45. Neggers SJ, de Herder WW, Janssen JA, Feelders RA, van der Lely AJ (2009) Combined treatment for acromegaly with longacting somatostatin analogs and pegvisomant: long-term safety for up to 4.5 years (median 2.2 years) of follow-up in 86 patients. Eur J Endocrinol 160(4):529-533 